\title{
Research on Engineering Insurance Issues in Public Procurement in China
}

\author{
Huang Jiangyu, Chengqian Xie* \\ College of Big Data Application and Economics, Guizhou University of Finance and Economics, Guiyang, P. \\ R. China
}

Keywords: public procurement, engineering insurance, risk management, business environment

\begin{abstract}
Engineering construction plays an important role in economic and social development. The scale of public procurement engineering projects in China is expanding. The risk management of engineering projects in public procurement is the key to enhancing the economic efficiency of enterprises and the quality of engineering construction. This study uses big data and case methods to sort out the low degree of application of engineering insurance, the lagging development of engineering insurance products, the need to improve engineering insurance professionals, the insufficient ability to identify risks, the inadequate recognition of the organizational design of project engineering, and the awareness of risks in construction Weakness and lack of effective post-evaluation system. The main suggestions for improving the above problems include: promoting engineering insurance with the aim of improving the business environment, improving the risk management capabilities of various entities in engineering insurance, promoting the diversification of the supply of engineering insurance products, and strengthening the top-level design of engineering insurance for public procurement.
\end{abstract}

\section{Introduction}

Since the 70th anniversary of the founding of New China, China has made great achievements in major infrastructure construction, such as the Hong Kong-Zhuhai-Macao Bridge, Beijing Daxing International Airport, and subway projects in major cities. While achieving great development, we also found that if large-scale projects are constructed with different risk prevention measures, they will face huge risks. For example, in recent years, accidents such as the Shanghai Metro, the new CCTV site, and the Wuxi viaduct in Jiangsu have caused public procurement risks Management, engineering insurance, etc. have become the focus of social attention. In this research, we searched cnki.net based on the keywords "public procurement", "risk", and "engineering insurance", and found that there is less research on engineering insurance for public procurement engineering projects. This research studies the connotation and evolution of engineering insurance, existing problems, reasons, and suggestions for improvement.

\section{Connotation and Development History of Engineering Insurance in public procurement}

Engineering insurance is a gambling agreement on personal and property safety conducted by policyholders and insurers based on the diversified risks of project construction to absorb losses within the scope allowed and protected by law [1]. Its significance lies mainly in decentralizing the responsibilities of the parties involved in the construction process, thereby improving the quality of construction projects, purifying the competitive environment of the construction engineering market, and providing benefits for all parties [2]. In China, the research of engineering insurance is still in its infancy, and most of the research content is to analyze and explore the status quo or slow development of engineering insurance in China, as well as countermeasures and suggestions. The development trend of engineering insurance will diversify with the diversity of engineering disciplines and the innovative development of its own insurance types. The research industry will also transition from a single construction industry to an infrastructure construction industry. The scope of research will still focus on practical aspects, covering the engineering phase will be more detailed [3]. 
The application of engineering insurance in large-scale public procurement engineering projects such as water conservancy and hydropower in China is relatively late, and the 2014 version of the "Water Conservancy Engineering Design Budget (Estimation) Compilation Regulations" affirmed the project insurance from an investment control perspective an important function in the construction of water conservancy and hydropower projects. In 2015, the National Development and Reform Commission and the China Insurance Regulatory Commission jointly issued a document emphasizing the vigorous development of engineering insurance. At present, there is a large number of non-insured conditions in China's public procurement. On the one hand, most of the project budget estimates for infrastructure projects under state financial appropriation do not involve engineering insurance costs, resulting in many construction projects not being insured. On the other hand, the inadequate insurance system, the poor legal environment related to engineering insurance, and inadequate technical expertise also have important impacts [4]. The pain points of insured engineering insurance in public procurement are mostly related to inadequate technical requirements for the cause of insurance in underwriting and claims [5]. In order to promote the development of engineering insurance, the engineering insurance itself should be enriched to improve the current types of insurance, strengthen relevant system legislation, strengthen supervision, improve the technical level of professionals, etc., and improve the application level of engineering insurance in public procurement. First, reform the accounting system in engineering cost [6].

The current research of engineering insurance mainly focuses on two aspects: first, the status and problems of engineering insurance development, and research on countermeasures and suggestions for solving problems. Second, how to use engineering insurance to avoid risks and reduce losses in the risk management of engineering construction. It can be seen that there is less research on engineering insurance issues in public procurement in China, and less discussion of common problems and solutions to engineering insurance in public procurement projects. Therefore, this research studies the connotation and evolution of engineering insurance, existing problems, reasons, and suggestions for improvement.

The connotation of engineering insurance can be defined in broad and narrow sense [7]. In a broad sense, engineering insurance refers to a collective term for comprehensive insurance solutions in engineering construction projects. It is not limited to all risks of construction engineering in general or all risks of installation engineering. The risks involved are not only risks in the construction process but also impacts. Other indirect risks of engineering construction. In a narrow sense, engineering insurance refers to insurance for basic risks such as all risks in construction projects and all risks in installation projects [8]. This article considers that engineering insurance in public procurement refers to the subject of third party liability incurred during the construction process due to natural disasters or accidents caused by various types of construction projects under public procurement procedures as the object of insurance. The underwriting risk of engineering insurance in public procurement is fundamentally different from the risks of ordinary property insurance targets, and its insured targets are mostly used in large-scale infrastructure construction and public service supply. Engineering insurance has the characteristics of large scale of insurance, complicated technical requirements for insurance, and long risk period. Since the 70th anniversary of the founding of the new country, China's engineering insurance has continued to break through and develop.

\section{Analyze the Existing Problems of Engineering Insurance in Public Procurement Based on Big Data}

The problems of engineering insurance in China's public procurement include: low application of engineering insurance, lagging development of engineering insurance products, and the need to improve the talents of engineering insurance professionals.

\subsection{The application of engineering insurance in China is relatively low}

Engineering insurance is an important means of risk management and risk protection in the 
economic market environment of engineering construction. However, only some government-owned municipal projects in China's engineering insurance projects are insured, and most of the insured objects are Chinese-foreign joint ventures. Since then, the insurance coverage of China's engineering insurance has only been $10 \%$ of the total investment in fixed assets of the whole society in the same period, which is far from the proportion of insurance projects with insurance rates of more than $90 \%$ in developed countries.

Judging from the growth rate of premiums, the growth rate of property insurance premiums has gradually flattened, while engineering insurance has experienced huge fluctuations, is extremely unstable, and has experienced negative growth. In the first nine months of 2019, China's property and casualty insurance companies realized a total of 976.8 billion Yuan in premium income, a year-on-year increase of $10.89 \%$. The original premium income of engineering insurance was less than 10 billion yuan, accounting for less than $1 \%$.

Since 2008, the proportion of engineering insurance in property insurance has decreased year by year from $1.60 \%$ in 2008 to $1.03 \%$ in 218 , which is obviously in line with the development of large-scale public infrastructure construction in China Disproportionate relationship(table 1).

Table 1 Development status of engineering insurance in China from 2008 to 2018.

\begin{tabular}{|c|c|c|c|c|c|}
\hline Years & $\begin{array}{c}\text { Engineering insurance } \\
\text { premium income (100 } \\
\text { million Yuan) }\end{array}$ & $\begin{array}{c}\text { Property insurance } \\
\text { premium income (100 } \\
\text { million Yuan) }\end{array}$ & $\begin{array}{c}\text { Engineering } \\
\text { insurance } \\
\text { growth rate }\end{array}$ & $\begin{array}{c}\text { Property } \\
\text { insurance } \\
\text { growth rate }\end{array}$ & $\begin{array}{c}\text { Proportion of } \\
\text { engineering } \\
\text { insurance }\end{array}$ \\
\hline 2008 & 39.23 & 2446.25 & $24.62 \%$ & $17.24 \%$ & $1.60 \%$ \\
\hline 2009 & 51.6 & 2992.9 & $31.53 \%$ & $22.35 \%$ & $1.72 \%$ \\
\hline 2010 & 70.9 & 4026.89 & $37.40 \%$ & $34.55 \%$ & $1.76 \%$ \\
\hline 2011 & 73.8 & 4779.06 & $4.09 \%$ & $18.68 \%$ & $1.54 \%$ \\
\hline 2012 & 62.26 & 5529.88 & $-15.64 \%$ & $15.71 \%$ & $1.13 \%$ \\
\hline 2013 & 78.61 & 6481.16 & $26.26 \%$ & $17.20 \%$ & $1.21 \%$ \\
\hline 2014 & 81.67 & 7544.40 & $3.89 \%$ & $16.41 \%$ & $1.08 \%$ \\
\hline 2015 & 82.93 & 8423.26 & $1.54 \%$ & $11.65 \%$ & $0.98 \%$ \\
\hline 2016 & 93.34 & 9266.71 & $12.55 \%$ & $10.01 \%$ & $1.01 \%$ \\
\hline 2017 & 100.24 & 10541.38 & $18.10 \%$ & $13.76 \%$ & $0.95 \%$ \\
\hline 2018 & 120.79 & 11755.69 & $9.57 \%$ & $11.52 \%$ & $1.03 \%$ \\
\hline
\end{tabular}

In terms of premium income, the premiums of engineering insurance have been increasing year by year, but their share in property insurance has gradually decreased. Judging from the growth rate of premiums, the growth rate of property insurance premiums has gradually flattened, while engineering insurance has experienced huge fluctuations, is extremely unstable, and has experienced negative growth. As can be seen from Figure 3, in the first nine months of 2019, China's property and casualty insurance companies realized a total of 976.8 billion Yuan in premium income, a year-on-year increase of $10.89 \%$. The original premium income of engineering insurance was less than 10 billion yuan, accounting for less than $1 \%$.

\subsection{Development of engineering insurance products lags behind}

At present, the insurance rates of major projects related to engineering insurance in China are relatively low compared to the average rates in the international market. The rate of some projects is only about $1 / 2$ of the international level. Most of the domestic insurance company's premium determination methods are based on the calculation of the loss rate. The loss rate is closely related to the risk factors affecting the construction of the project. The risk factors for different project projects are different, so the loss rate is only calculated according to the existing statistics. , Ignore the potential risks in the project. In this paper, we have collected the water conservancy and hydropower engineering insurance service projects in some provinces and cities in recent years by searching the official websites of public resource trading centers in Guizhou, Tibet, Jiangxi, Anhui, 
and other provinces, the official website of Water Conservancy and Hydropower Construction Corporation, and the Chinese government procurement website. The rate of engineering insurance in the table is basically between $0.2 \%$ and $0.5 \%$, which is generally lower than the rate of similar insurance types in foreign countries.

\section{Suggestions for Perfecting Engineering Insurance in public procurement}

\subsection{Promote engineering insurance with the goal of improving the business environment}

Major projects in China's major water conservancy and hydropower projects, transportation and road projects, assistance in poverty alleviation, and rural revitalization have accompanied China's high-quality economic and social development [8]. In 2019, the Ministry of Finance issued the "Notice on Promoting Fair Competition in public procurement and Optimizing the Business Environment", and the State Council passed the "Regulations on Optimizing the Business Environment", which imposes higher requirements on risk management in public procurement and the risks of procurement of engineering projects Management is an important guarantee for the government to optimize the business environment for public procurement. China implements strict scientific and effective public procurement engineering construction management methods and preventive guarantee mechanisms, and improving the application of engineering insurance in public procurement engineering projects will be an inevitable need for China's economic and social development.

China should attach importance to the government's risk management capabilities, improve project companies' insurance awareness, and provide insurance companies with more diversified insurance products. Strengthen the research on engineering insurance theory, improve comprehensive ability, and cultivate high-quality dual-energy engineering insurance professionals. With the goal of building a business environment, it is particularly important to strengthen the integrity awareness of all parties in the insurance industry to promote the integrity of the engineering insurance industry [9]. Promote the construction of a social credit management system, link the issue of integrity in engineering insurance with the social credit management system, and ensure the effective play of the role of engineering insurance.

\subsection{Enhance the risk management capabilities of various entities in engineering insurance}

Engineering insurance, as an effective risk avoidance method for property losses and third party liability caused by construction project accidents, has an irreplaceable role in preventing the occurrence of risk accidents and reducing the scope of risk accidents. The insurance awareness of contractors and other subjects should be effectively raised. An insurance system for public procurement projects is implemented, and the insurers composed of the construction unit and the construction unit apply for insurance to the insurance company. The insurance company's safety and quality risk management of the project can effectively reduce the risk of the entire process of the project construction.

As an important link between the insurer and the insurer, China should actively encourage the development of highly specialized intermediary companies in the field of engineering insurance and provide them with a good development environment and policy support in various aspects [10]. The deepening of the depth of cooperation between various intermediary companies and insurance companies is conducive to greatly improving the professionalism in the underwriting process. The assessor in an intermediary company has a fair and just position, and professional demonstrations in large-scale engineering insurance are conducive to improving the effectiveness of risk management.

\subsection{Promote the diversification of the supply of engineering insurance products}

According to the Qingdao Metro insurance case, it can be found that the current engineering insurance mainly covers general insurance and liability insurance, and less insurance for certain special important risks, that is, the project company invests too much premium in secondary risks, and the proximate risk of the accident May be in insurance exclusion. This kind of 
non-differentiated, non-personalized insurance product is more difficult to meet the needs of policyholders. The insurance types of existing engineering insurance in China are mainly based on all risks of construction engineering, all risks of installation engineering, and accidental injury of employees. Engineering insurance in China's public procurement should increase the diversification of supply to meet the needs of engineering projects. Specific requirements. China should encourage and support insurance companies to effectively promote the innovation of engineering insurance in accordance with the economic and social development trends and corporate requirements of China, combined with the successful experience of overseas engineering insurance. Relevant government departments in China can standardize and guide the healthy development of the industry according to the standard contract texts and special contract texts of different types of engineering insurance.

\subsection{Strengthening the top-level design of engineering insurance in public procurement}

System design is the key to determining whether engineering insurance can operate effectively. In China, we can develop contract performance guarantee insurance and engineering quality potential defect insurance through legislation and other forms to promote the development of the insurance market and increase the ability of public procurement projects. The importance of engineering insurance can be further clarified in the "Tendering and Bidding Law" being revised. Play a leading role in legislation through legislation. The ability of engineering insurance in public procurement to play a supporting role is closely related to the requirements of bidding documents. Government departments should be strengthened to increase the consciousness of engineering insurance application, and to extend engineering insurance throughout the entire life cycle of procurement, performance and acceptance of engineering projects. Attention is paid to the normative review of engineering insurance and the effectiveness of the entire process in the bidding documents. The China Banking and Insurance Regulatory Commission and the Insurance Industry Association should strengthen the supervision and management of insurance companies in engineering insurance, formulate regulatory documents that help promote the standardized development of the engineering insurance industry, and ensure the regulatory effectiveness of engineering insurance.

\section{Acknowledgements}

This paper is based on a research project financially supported by Guizhou University of Finance and Economics Teaching Quality and Teaching Reform Project (2019), entitled "Research on Teaching Reform of Property Insurance Courses under the Background of Big Data”(Grant number: 2019JGZZC07) and financially supported by "China Solution for Targeted Poverty Alleviation: Research on the Poverty Reduction Effect of PPP Model” (Grant number: 2019YJ041).

\section{References}

[1] Jiang Ansheng. Talking about engineering insurance in large-scale engineering construction. Voice of the People, 2018 (08): 50-52.

[2] $\mathrm{Hu}$ Jianwen. The Present Situation and Future of Engineering Guarantee and Engineering Insurance in China. Architecture, 2000 (03): 26-27.

[3] Yu Hongliang, et al. Research on Water Conservancy and Hydropower Engineering Insurance from the Perspective of the Insurant__-Based on the Bidding Case Data from 2015 to 2019. Journal of Wuhan Vocational College of Transportation, 2019, 21 (03): 55-60.

[4] Li Jie. Research on the way to overcome technical barriers to engineering insurance and risk management model. Huaqiao University, 2011.

[5] Yang Xiaomei. Some suggestions on risk identification and risk control in engineering insurance_-A case study of Xibao high-speed railway engineering insurance . Finance and Economics (Academic Edition), 2015 (08): 136. 
[6] Yu Qin. Problems existing in China's engineering insurance system and improvement measures. Value Engineering, 2010, 29 (15): 38.

[7] Deng Tiejun. Engineering risk management. Beijing: People's Communications Press, 2004.

[8] Zhao Xiaowei. Analysis on the application of engineering insurance in the implementation of large-scale engineering construction. Science and Technology Bulletin, 2016, 32 (06): 113-117.

[9] Zhang Jianbin, Zhang Nannan. Research on Engineering Risk Management and Engineering Insurance System in China. Infrastructure Optimization, 2003, (2): 21-24

[10] Zhang Yonglin. Study on construction quality risk management in municipal engineering projects. Transportation World, 2019 (27): 142-143. 